Authors: Andrzej Kawalec, Anna Bazan

Title of article: „Ilościowy opis form zużycia jednowarstwowych ściernic z cBN, pracujących z różnymi prędkościami szlifowania” ("Quantitative description concerning wear forms of cBN single-layer grinding wheels working with different grinding speeds")

Mechanik, Vol. 91, No. 10 (2018): pages 803-805

DOI: https://doi.org/10.17814/mechanik.2018.10.134

\title{
Quantitative description concerning wear forms of cBN single-layer grinding wheels working with different grinding speeds
}

\author{
Ilościowy opis form zużycia jednowarstwowych ściernic z cBN, \\ pracujących z różnymi prędkościami szlifowania
}

\begin{abstract}
ANDRZEJ KAWALEC ANNA BAZAN *
\end{abstract}

The paper presents a method of quantifying the observed wear forms of electroplated $\mathrm{CBN}$ grinding wheel. The volume of fractured, pulled out or smeared abrasive was determined. Three grinding wheels working with different grinding speeds were tested.

KEYWORDS: grinding wheel topography, grinding wheel wear, single-layer grinding wheel

Knowledge about the forms of grinding wheel active surface (GWAS) allows for a better understanding of the phenomena occurring on the grinding wheel during its operation. However, the qualitative and quantitative evaluation of wear of grinding wheels requires the application of various methods for data quantification and their further analysis. These methods may take into account two or three dimensional data obtained from observation/ measurement of GWAS. Due to the large amount of data, their analysis should be based on computer methods.

Studies on various forms of GWAS wear are most often based on the visual assessment of abrasive grains, bond and free space on GWAS. For this purpose, 2D images of GWAS are needed at the appropriate magnification, obtained in microscopic studies, e.g. on optical microscopes or electron force microscopes (SEM). Thanks to the good quality 2D GWAS images, a researcher who understands knowledge and experience can recognize different forms of GWAS wear. However, this is only quality information about the wear processes that the abrasive consumes. The quantitative assessment is more demanding and depends on the design and forms of grinding wheel wear.

When analyzing microscopic images, the user can count the grains which have been subject to various types of wear [1-5]. This is an accurate method, but it is very timeconsuming, so the analysis area is usually small. For this reason, image analysis methods are often used to recognize and quantify various forms of wear based on 2D images. In this way, you can specify wear flat area on grains $[2,6]$ and percentage of smears [6].

The concept of quantitative assessment of wear forms based on $3 D$ data from topography measurements was presented, among others, in articles [7, 8]. It assumes the detection of flat areas. Depending on their size, they are categorized as smears or surfaces subjected to attritious wear.

\footnotetext{
* Dr hab. inż. Andrzej Kawalec (ak@prz.edu.pl), mgr inż. Anna Bazan (abazan@prz.edu.pl) - Politechnika Rzeszowska
}

Computer methods in comparison to methods based only on the researcher's work may be less precise (due to unavoidable errors of automatic image analysis - in the case of grinding wheels this analysis is focused on the recognition of grains and bond), but allow for quick, automatic analysis of larger GWAS areas and calculation of a larger set of parameters.

Similarly, greater possibilities of analysis in comparison with methods based on 2D data are provided by methods that take into account three-dimensional information about GWAS.

The approach presented in the article to determine the amount of abrasive that has undergone specific forms of wear, assumes measuring the topography of the grinding wheel. As in the studies described in [7], the smears was distinguished from the grains on the basis of their area. Additionally, it was possible to determine the volume of the fractured abrasive and pulled out from the bond. During the tests, it was checked how the proportion of individual forms of GWAS wear depends on the grinding speed $v_{\mathrm{s}}$.

\section{Subject and methodology of research}

The subject of the research was the topography of the active surface of three monolayer wheels with a cBN abrasive with grain number B35 (average grain size $d_{g}=35 \mu \mathrm{m}$ ) at various stages of wheel wear.

The nickel bond of the grinding wheels was applied to the grinding wheel using the galvanizing method. The thickness of the bond layer was $50 \div 60 \% \cdot d_{g}$.

The grinding wheels were conical in shape, with an angle of cone of $140^{\circ}$ and an average diameter of the active surface of $87.2 \mathrm{~mm}$.

Workpieces were made of high-alloy steel with a hardness exceeding 81 HRA. Each grinding wheel worked with a different set of grinding parameters. In each of the three cases, the feed speed and grinding depth were $v_{\mathrm{w}}=4250 \mathrm{~mm} / \mathrm{min}$ and $a_{\mathrm{e}}=20 \mu \mathrm{m}$, while depending on the grinding wheel the grinding speed $v_{\mathrm{s}}$ was set at $18.3 \mathrm{~m} / \mathrm{s}$ (in the case of the $S 1$ grinding wheel), $27.4 \mathrm{~m} / \mathrm{s}$ (in the case of the S2 wheel) and $36.5 \mathrm{~m} / \mathrm{s}$ (in the case of the S3 wheel).

The topography of grinding wheels was reproduced by means of silicone rubber replicas (giving the possibility of reproducing details above $0.1 \mu \mathrm{m}$ ) with black color, made using the Struers RepliSet system. The InfiniteFocus microscope manufactured by Alicona with an $\times 20$ lens was used to measure the topography of GWAS replicas. The vertical resolution of the measurement was $0.1 \mu \mathrm{m}$. 
Six identical (approximately) GWAS areas measuring 2.25 $\mathrm{mm} \times 2.50 \mathrm{~mm}$ were measured at various stages of the wheel wear.

Processing of measurement data along with the separation of particles, corresponding to grains and smears, and pores, as well as the determination of their parameters were carried out in the SPIP 6.4.2 program. The methodology of particles and pores separation is presented in the article [9]. The distinction between grains and smears was based on the analysis of the surface area of the particle. The smear was considered to have a surface area greater than or equal to $2,500 \mu \mathrm{m}^{2}$ - otherwise the particle was considered to be the area corresponding to the abrasive grain (Fig. 1). The boundary value of the grain and stickiness was assumed at such a level, because on each of the new grinding wheel topography analyzed, at least $99 \%$ of the grains had an area smaller than $2500 \mu \mathrm{m}^{2}$.

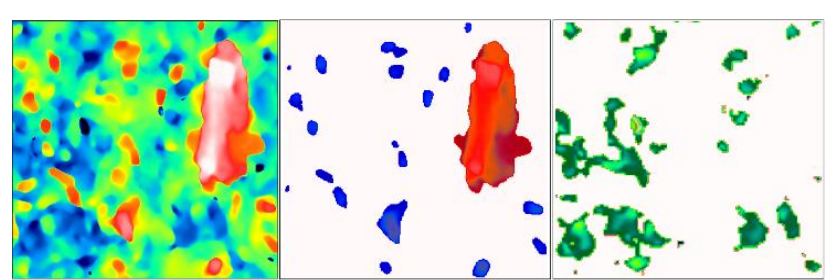

Fig. 1. An exemplary fragment $(0.5 \mathrm{~mm} \times 0.5 \mathrm{~mm})$ of the measured GWAS surface (left) and separated particles (in the middle) and pores (on the right). In the view showing the particles, the red area corresponds to smear and blue to grains

\section{Determination of the volume percentage share of individual forms of GWAS wear}

Visual evaluation of photos of GWAS replicas and topography maps allowed to determine that changes in GWAS during the durability period of the grinding wheels were mainly related to three types of wear [10]: grain fracture, pull out from the bond and GWAS smearing.

Parameters of particles, pores and smears were used to calculate the percentage share of particular types of wear. On the basis of a known volume of abrasive on GWAS, expressed in the Vsum parameter (volume of grains per GWAS area unit) - on different grinding wheel stages (i.e. after removal of different material volume) and on the new grinding wheel - abrasive loss due to wear $d V$ sum was determined. Thus, a loss of abrasive was known at a given stage of the grinding wheel operation, which is the result of all types of wear:

$$
d V s u m=V w y k r+V w y r w+V z a l e p
$$

where: $d V$ sum $\left[\mu \mathrm{m}^{3} / \mathrm{mm}^{2}\right]$ - total abrasive loss at a given grinding wheel, $V w y k r\left[\mu \mathrm{m}^{3} / \mathrm{mm}^{2}\right]$ - volume of fractured abrasive, Vwyrw $\left[\mu \mathrm{m}^{3} / \mathrm{mm}^{2}\right]$ - volume of pulled out abrasive, Vzalep $\left[\mu \mathrm{m}^{3} / \mathrm{mm}^{2}\right]$ - the abrasive volume that has been covered by smears.

The research methodology did not allow to distinguish between micro-and macro-fractures of cBN grains.

According to the manufacturer's data, the thickness of the bond layer is $50 \div 60 \%$ of the average grain size, which is why it was assumed that $45 \%$ of the grain volume was above the bond. It was assumed that the volume of a recess in the bond remained after grain pull out was $55 \%$ of the grain volume. On the basis of the difference in the pores volume at a given stage of the tests $\operatorname{Vsum}(p)$ and the pores volume on the new grinding wheel $\operatorname{Vsum}(p)_{0}$, the abrasive volume was calculated, which was pulled out of the bond (the abrasive volume which initially protruded above the bond level):

$$
V w y r w=\left(\operatorname{Vsum}(p)_{0}-\operatorname{Vsum}(p)\right) \cdot(0,55 / 0,45)
$$

It was left to calculate the volume of the fractured and covered by smears abrasive. Grains which were surrounded by a material forming a smear of the intergranular space were considered to be smeared. The volume of smeared grains Vzalep was determined approximately based on the percerntage of smears $A \%(z)$ on a given wear stage:

$$
\text { Vzalep }=V_{\text {sumo }} \cdot A \%(z)
$$

where: Vsum $0\left[\mathrm{~mm}^{3} / \mathrm{mm}^{2}\right]$ - abrasive volume on a new grinding wheel.

The volume of fractured grains was determined after the equation was transformed (3). Referring the volume of fractured, pulled out and smeared grains to the total loss of abrasive at a given stage of work of grinding wheel $d V$ sum, the percentage share of particular types of wear was obtained. The percentage of abrasive subjected to a given process of wear was calculated.

\section{Test results}

As a result of grinding processes, grinding wheels $\mathrm{S} 1$ and $\mathrm{S} 2$, working with grinding speeds equal to $18.3 \mathrm{~m} / \mathrm{s}$ and 27.4 $\mathrm{m} / \mathrm{s}$, were completely worn, which was manifested by a sharp increase in grinding force [10] - this increase was taken as a criterion for determining the end of grinding wheel life.

After observing the increase in the grinding force, the grinding process was interrupted and the grinding wheel was considered to be completely wear. The total wear of the grinding wheel S1 occurred after removal of the specific material volume $V^{\prime}=59 \mathrm{~mm}^{3} / \mathrm{mm}$ in $0.7 \mathrm{~min}$, and the grinding wheel $\mathrm{S} 2$ - after removing the specific volume $V^{\prime}=680$ $\mathrm{mm}^{3} / \mathrm{mm}$ during $8 \mathrm{~min}$. The grinding wheel S3, operating at the highest grinding speed, was not completely worn during the tests. Due to the limited number of grinding samples, the tests were discontinued after achieving a material loss equal to $V^{\prime}=2652 \mathrm{~mm}^{3} / \mathrm{mm}$. The working time of the S3 grinding wheel was 31.2 minutes.

It can be deduced from the quoted data that the speed of grinding $v_{s}$ significantly affected the wear and durability of the grinding wheel. The increase in the grinding speed resulted in the reduction of grinding wheel wear and the extension of its durability period. It was related to the reduction of the grinding force along with the increase of $v_{s}[10]$.

The total abrasive loss of grinding wheels S1 and S2, which were completely worn, was respectively $94 \%$ and $91 \%$ of the initial volume of abrasive. $70 \%$ of the available grain volume has been worn on the S3 grinding wheel.

Fig. 2 and fig. 3 present a quantitative description of the wear forms of the tested grinding wheels.

During the tests, the most grain material, over $88 \%$, was fractured in the form of grain fragments from grinding wheel S1, working with the smallest grinding speed. From the grinding wheel S2, which has also completely worn out, about $77 \%$ of abrasive material has been fractured. The volume share of the fractured abrasive was the highest in the case of the S2 wheel. The volume of fractured grains in the four tested states of the grinding wheel changed slightly, while the share of abrasive pulled out from the bond clearly increased.

This is also confirmed by the diagrams in fig. 3 , showing the share of abrasive volume that has been subjected to particular types of wear, in relation to the total loss of grain material at a given stage of the grinding test. Regardless of the grinding speed and the volume of the material removed, the dominant wear process was grain fracture.

In the case of S1 and S2 grinding wheels, more abrasives were pulled out of the bond than was subjected to attritious wear. In the case of the S3 grinding wheel, operating at the highest grinding speed, the abrasive was almost exclusively 
fractured. Only after the final stage of the grinding wheel operation was there a clear increase in the share of grains pulled out.

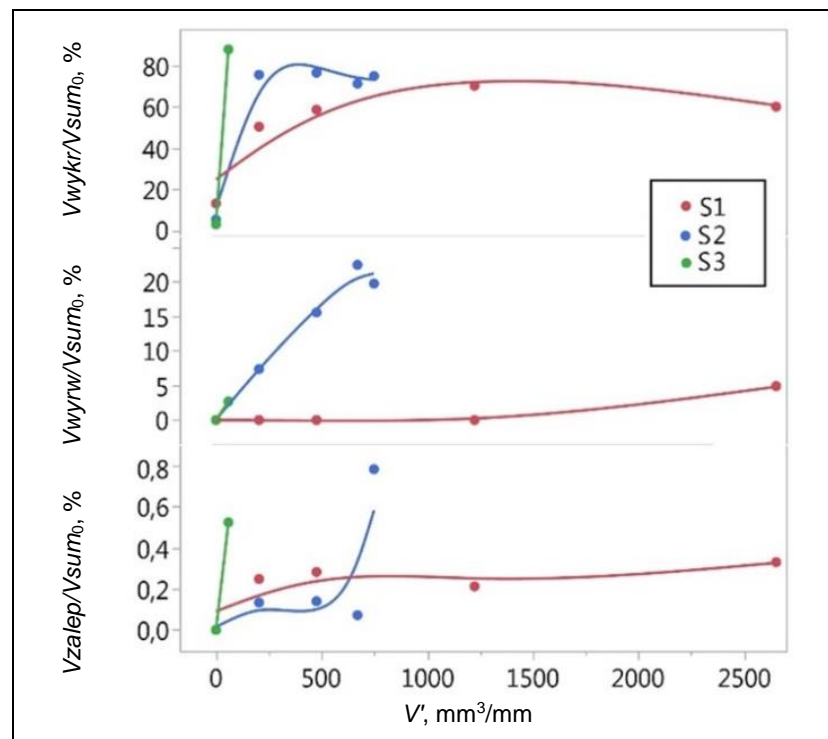

Fig. 2. Percentage share of abrasive volume, which has been subjected to various types of wear on grinding wheels S1, S2 and S3 after removal of the specific material volume $V$ '(to improve the readability of the drawing, lines approximating values for S2 and S3 have been introduced)

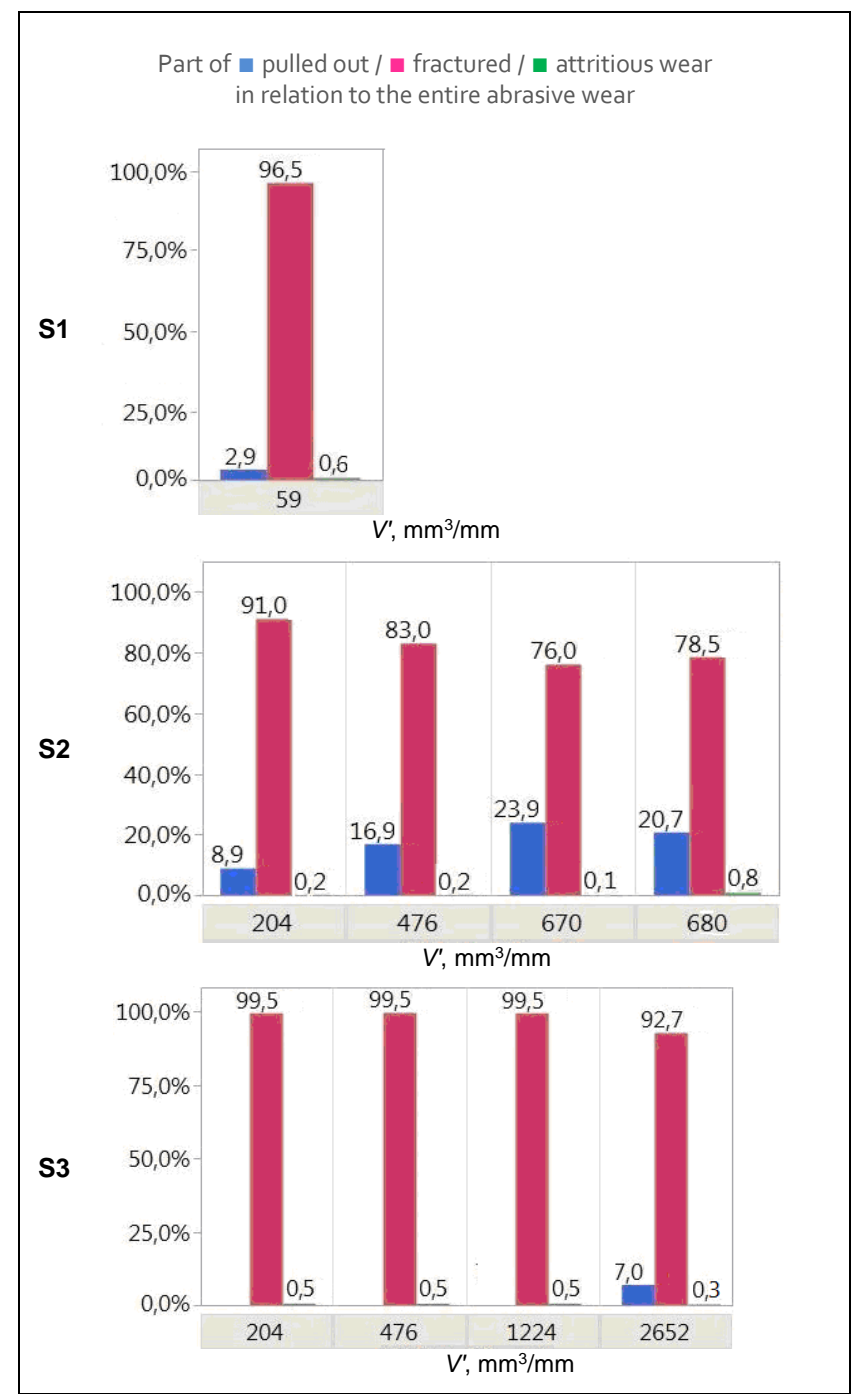

Fig. 3. Percentage share of abrasive volume, which has been subject to various types of wear on grinding wheels S1, S2 and S3 after removal of the specific material volume $V^{\prime}$ in relation to the volume of all abrasive wear

\section{Conclusions}

The type of wear processes affects the way wheel grinding microgeometry is shaped, and thus determines the machining properties of the grinding wheel. For this reason, the analysis of the intensity of various wear processes can be helpful in designing and supervising grinding processes.

Considering the types of wear analyzed in the article, the least unfavorable from the point of view of the grinding wheels performance is fracture, and especially micro-fracture of grains. In the case of grains being smeared, GWAS loses the cutting potential that was associated with these grains. Smearing is also associated with the loss of cutting properties by grains, which were somehow obstructed by the incrustation of the workpiece material. In addition, the appearance of smears adversely affects the friction conditions, increases grinding power and temperature in the grinding area.

Fractures of grains causes a loss of abrasive material, so it is an unfavorable phenomenon, however, on the other hand, it causes that new, sharp cutting edges are exposed. The microfractures of grains is the most advantageous form of wear from the point of view of grinding wheel. It does not cause significant loss of abrasive, and at the same time contributes to the self-sharpening of the grinding wheel.

On the basis of the conducted research it was shown that the grinding speed affects not only the durability of the grinding wheel but also the intensity of various wear processes. Regardless of the grinding speed, the dominant process of GWAS wear was grain fracturing.

\section{REFERENCES}

1. Deja M. „Ocena stanu czynnej powierzchni ściernicy ze spoiwem galwanicznym w szlifowaniu z kinematyką docierania”. Inżynieria Maszyn. 18, 2 (2013): pp. 45-54.

2. Hwang T., Malkin S., Evans J. "High speed grinding of silicon nitride with electroplated diamond wheels. Part 2: Wheel topography and grinding mechanisms". Journal of Manufacturing Science and Engineering. 122, 1 (1999): pp. 42-50.

3. Schoenhagen Y., Vasquez J. "Process Simulation of Mono-Layer Super Abrasive Grinding Wheels". Worcester Polytechnic Institute 2012.

4. Shi Z., Malkin S. "An investigation of grinding with electroplated CBN wheels". CIRP Annals - Manufacturing Technology. 52, 1 (2003): pp. 267-270.

5. Shi Z., Malkin S. "Wear of electroplated CBN grinding wheels" Journal of Manufacturing Science and Engineering. 128, 1 (2005): pp. 110-118.

6. Kapłonek W., Nadolny K. "Assessment of the grinding wheel active surface condition using SEM and image analysis techniques". Journal of the Brazilian Society of Mechanical Sciences and Engineering. 35, 3 (2013): pp. 207-215.

7. Kacalak W. i in. „Metody identyfikacji zmian stanu czynnej powierzchni ściernic w wyniku starcia, zalepienia lub wykruszania ziaren". XXXVII Naukowa Szkoła Obróbki Ściernej. Wrocław, 2014, pp. 193-199.

8. Lipiński D., Kacalak W., Tomkowski R. "Methodology of evaluation of abrasive tool wear with the use of laser scanning microscopy". Scanning. 36, 1 (2014): pp. 53-63.

9. Bazan A., Kawalec A. „Metody wyodrębniania ziaren z topografii czynnej powierzchni ściernicy jednowarstwowej”. XXXXI Naukowa Szkoła Obróbki Ściernej. 2018.

10. Kawalec A., Bazan A., Krok M. „Wpływ prędkości szlifowania na zużywanie się ściernicy z nasypem z cBN, ze spoiwem nanoszonym galwanicznie". Mechanik. 8-9 (2017): pp. 690-692.

Translation of scientific articles, their computer composition and publishing them on the website www.mechanik.media.p by original articles in Polish is a task financed from the funds of the Ministry of Science and Higher Education designated for dissemination of science.

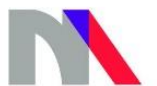
and Higher Education 